\title{
THE AFRICAN CHARTER ON HUMAN AND PEOPLES' RIGHTS, ITS REGIONAL SYSTEM, AND THE ROLE OF CIVIL SOCIETY IN THE FIRST THREE DECADES: CALIBRATING THE "PAPER TIGER"
}

\author{
Dejo Olowu \\ LLB(Hons) LLM PGDip JSD \\ Barrister and Solicitor (Nigeria) \\ Research Professor of Law, North-West University \\ Mafikeng Campus
}

\section{SUMMARY}

Neither has any other human-rights treaty received as much vitriolic bashing as the African Charter on Human and Peoples' Rights (African Charter), 1981, nor has there been a dearth of negativity about the treaty as a human-rights instrument. Such is the spate of pessimism about the African Charter and its system that it has repeatedly been referred to as "a paper tiger", among other undignified labels. Beyond the endless lampooning of the treaty and its system as mere platitudes, have there been no opportunities for the civil society to strengthen the promise of this treaty and its system. To what extent has the civil society exploited such opportunities? Can there be a reconceptualization of the roles and attitudes of civil society that will galvanize the African regional human-rights system towards a veritable mechanism for more effective human rights protection? This article examines the contributions of civil society to the evolutionary processes, successes, and perceived weaknesses of the African regional human-rights system since 1981. Extrapolating from some landmark institutional, normative and jurisprudential developments within the African regional arrangement, this article identifies civil society as an inevitable, integral bearer of credit for the successes, and blame for the shortcomings of the aforementioned system. The overarching objective here is to canvass for a repositioning of civil society towards more effective praxis, and, to identify the trajectories for such engagement.

INTRODUCTION

In an age when despots and dictatorial regimes held sway over much of Africa, the African Charter on Human Rights and Peoples' Rights (the African Charter), also commonly referred to as "the Banjul Charter", was adopted in June 1981, giving birth to the triumphs and travails that have marked the African experience in establishing a regional system of humanrights promotion and protection. Three decades after the emergence of the 
African Charter and a quarter of a century since its entry into force, it is apposite to explore the dynamic realities that have shaped the contours of the African regional human-rights system founded upon its precepts.

While so much effort - by attention-seeking writers, upstart researchers, sheer cynics, armchair commentators, and fair-weather activists within and outside Africa - has been devoted to the evaluation of the African Charter and the regional human-rights system founded upon it, such efforts have largely evaded bringing the civil society under identical spotlight. One gaping omission in most of the critical assessments of the African Charter, nay, the African regional human-rights system is that this treaty and indeed the entire regional human rights system based on it essentially mirror the quality of the civil society, reflecting the strength, ambivalence, or diminution of civil society activism. It is beyond polemics that the civil society has contributed much to the evolution of the African regional human-rights system and thus offers historians fertile insights in calibrating the strengths and weaknesses of the region's human-rights ethos.

Although not oblivious of the central role of African states as primary dutybearers of the guarantees of the African Charter, this article highlights perceptible indicators of the strategic character of civil society within the framework of the African Charter and the regional system founded upon it. Institutions of the African regional human-rights system have witnessed a diverse range of activism that include direct action, petitions, litigation, demonstrations as well as international and grassroots mobilization, among others. A fuller investigation of the civil society movement within the African regional arrangement promises to shed valuable light on the relationship between the global and the regional, between the national and the local, and to help in developing our awareness of the movement's complex internal dynamics, and enhance our perceptions around the correlation between the structural and philosophical challenges of civil society, on the one hand, and the effectiveness of the African regional human-rights system, on the other. In other words, it will help us to arrive at a more thorough understanding of the broader human-rights struggle in Africa itself. This is the background from which this article proceeds.

This article therefore begins with a discussion aimed at both problematizing and clarifying its key concept - "civil society" - a concept most frequently used and abused in literature on democratization, human rights, nation-building, conflict resolution, development, among others, yet not lending itself to disaggregation for uniform operational purposes. It proceeds to place the discussion in its proper African context and embarking on an analysis of its pertinence to the regional human-rights system. The final part reflects on the challenges of re-focusing and repositioning civil society in African countries and discusses some of the strategic implications of these concerns.

The overarching objective of this article is that the role of civil society in the three decades since the adoption of the African Charter needs to be explored more fully; and current developments across the continent offer exciting possibilities for scholars and activists to construct a more nuanced, and more useful, picture of calibrating the phenomena of effectiveness, 
reluctance, stagnation or retrogression in the African regional human-rights system.

\section{2 \\ "CIVIL SOCIETY": REFLECTIONS ON CONCEP- TUAL QUANDARIES}

Without doubt, non-governmental forces have been pivotal in the evolution of human rights in Africa's post-independence era. Expectedly, existing literature has paid much attention to the activities of non-governmental organizations (NGOs) in the continental human-rights arena. ${ }^{1}$ Literature on human-rights promotion and protection in contemporary normativization is often primarily interested in how the international community or international actors (be they states, international governmental or nongovernmental organizations, often Western or West-oriented) can intervene in building sustainable human-rights ethos at national, regional and global levels. ${ }^{2}$ What the literature often downplays, however, are the activities of several other actors and forces that influence the dynamic fabric of African regional human-rights systems, beyond established orthodoxies. The first dilemma in analysing human rights in Africa is therefore definitional.

Since the time of Aristotle, political thinkers have argued and disputed, yet failed to reach agreement regarding the meaning of the term "civil society". ${ }^{3}$ Even today, it continues to be described by scholars as a hazy concept. It is therefore predictable that the perceptible speed and simplicity with which civil society penetrated the human-rights discourse cloaks important conceptual dilemmas and functional shortcomings. The term "civil society" entered human-rights lexicon in the 1980s, and by the mid-1990s, it had become a catchphrase. Over the past two decades, an impressive body of literature on civil society and human rights has been produced, and efforts to strengthen civil society have become a common feature of the programmes of many international bodies, inter-governmental agencies and donor organizations. ${ }^{4}$ The role of local civil society actors, along with the increase

1 See, eg, Welch Jr Protecting Human Rights in Africa: Strategies and Roles of NonGovernmental Organizations (1995); Hollenbach "Solidarity, Development, and Human Rights: The African Challenge 1998 26(2) The Journal of Religious Ethics 305; Ibhawoh Human Rights Organisations in Nigeria: An Appraisal Report on the Human Rights NGO Community in Nigeria (2001); Motala "Non-Governmental Organisations in the African System" in Evans and Murray (eds) The African Charter on Human and Peoples' Rights: The System in Practice 1986-2000 (2002) 246; Teshome "Civil Society and Democratization in Africa: The Role of the Civil Society in the 2005 Election in Ethiopia" 2009 4(2) International Journal of Social Sciences 80; and Mundy, Haggerty, Sivasubramaniam, Cherry and Maclure "Civil Society, Basic Education, and Sector-Wide Aid: Insights from Sub-Saharan Africa" 2010 20(4-5) Development in Practice 484

2 Neumayer "Do International Human Rights Treaties Improve Respect for Human Rights?" 2005 49(6) The Journal of Conflict Resolution 925 929; and Bond "Civil Society on Global Governance: Facing Up to Divergent Analysis, Strategy, and Tactics" 200617 Voluntas 359.

3 Ghosh "NGOs, Civil Society and Social Reconstruction in Contemporary India" 200925 Journal of Developing Societies 229, 231; Neumayer 2005 49(6) The Journal of Conflict Resolution 929; and Bond 200617 Voluntas 359.

4 See generally Tsutsui and Wotipka "Global Civil Society and the International Human Rights Movement: Citizen Participation in Human Rights International Nongovernmental Organizations" 2004 83(2) Social Forces 587; Malena and Heinrich "Can We Measure Civil 
in the number of such actors, has been increasingly recognized. Non-state actors are often believed to be more efficient and suitable to work for human rights than state actors, as they are more visible, less expensive, more flexible, less constrained by narrow mandates, and able to talk to several parties without losing their credibility and to deal directly with the grassroots population. ${ }^{5}$ The civil society concept, originating from political theory, but recently also brought into human-rights discourse, is used to describe the fact that people meet, communicate, and organize in ways that are not established or controlled by the state, nor by kinship and family ties, and with purposes that are driven neither by the power logics of the state nor by market interests. In the civil society arena, therefore, people voluntarily organize to defend common interests or work for social and political change. Colloquially, however, "civil society" has come to connote narrowly formal, non-governmental voluntary organizations that are generally presumed to promote public good. ${ }^{6}$

Some scholars define "civil society" as "an area of association and action independent of the state and the market in which citizens can organize to pursue purposes that are important to them, individually and collectively". Others used the term to refer to "organised groups or associations that are separate from the state, enjoy some autonomy in relations from the state, and are formed voluntarily by members of society to protect or extend their interests, values or identities". 8 The Commission of European Communities defines it thus:

"Civil society includes the following groups: trade unions and employers' organisations (social partners); organisations representing social and economic players which are not social partners in the strict sense of the term ... non-governmental organisations which bring people together in common cause, such as environmental organisations, human rights organisations, charities, professional associations, grass roots organisations; organisations that involve citizens in local and municipal life with a particular contribution from churches and religious communities."

Malena and Heinrich feel that despite its varied interpretations, civil society can be roughly understood as the space in society where collective citizen action takes place, although they admit that this notion of a societal space animated by a complex set of actors, activities, interests, and values has in fact proved extremely difficult to operationalize.

Society? A Proposed Methodology for International Comparative Research" 2007 17(3) Development in Practice 338 339; and Hyden and Hailemariam "Voluntarism and Civil Society Ethiopia in Comparative Perspective" 2003 38(2) Africa Spectrum 215.

5 Munck "Global Civil Society: Royal Road or Slippery Path?" 200617 Voluntas 325.

6 Currin "Summing Up: Civil Society Organisations in Emerging Democracies" in Micou and Lindsnaes (eds) The Role of Voluntary Organisations in Emerging Democracies (1993) 165.

7 Brown, Khagram, Moore and Frumkin "Globalization, NGOs and Multisectoral Relations" in Nye and Donahue (eds) Governance in a Globalizing World (2000) 275.

8 Manor, Robinson and White Civil Society and Governance: A Concept Paper (1999) quoted in Mundy, Haggerty, Sivasubramaniam, Cherry and Maclure "Civil Society, Basic Education, and Sector-Wide Aid: Insights from Sub-Saharan Africa" 2010 20(4-5) Development in Practice 485.

9 Commission of European Communities (2001): European Governance: White Paper, COM, 428 Brussels 25 July 200114. 
These conflicting visualizations of civil society has led to a noticeable disconnection between the theory of civil society and the practice of efforts to support civil society; or between the abstract idea of civil society and civil society as an observable reality. Where does civil society begin and where does it end? One finds that over time, references to "civil society" have been used to stand for NGOs, non-profit organizations (NPOs), community-based organizations (CBOs), peoples' organizations (POs), governmental nongovernmental organizations (GONGOs), international non-governmental organizations (INGOs), and so on, within different paradigms, sometimes leading to the erroneous total compartmentalization of "civil society" away from government, non-profit, community-based, faith-based or other voluntary organizations. This lack of appropriate conceptualization has also resulted in a dearth of empirical knowledge about civil society as a practical reality. It is now increasingly recognized that scientific and practitioner communities know little about the strength and shape of civil society around the world, let alone the factors fostering or inhibiting its strategic roles. ${ }^{10}$

The rapid ascension of civil society as a key human-rights theme thus contrasts with its rather chequered history as a complex and ambiguous political concept. This will not be an appropriate forum to review its origins. ${ }^{11}$ More germane for our present purpose is the proper contextualization of the civil society in assessing the triumphs and travails of the African regional human-rights system.

Undergirding the narrative of the African regional human-rights system are theories of the state and civil society. Briefly, the normative promotion of civil society, defined in culturally-specific "Western" terms, usually theorizes it as locked in a zero-sum opposition against the state. ${ }^{12}$ This binary logic has moral dimensions. The African state is demonized as the locus of oppression, having a monopoly on the use of force. Civil society thus represents the grassroots democratic spirit of modern African societies, a watchdog offering a check on the abuses of state power. ${ }^{13} \mathrm{~A}$ clear political project soon emerged that focused on what Kofi Annan once called "holding states' feet to the fire". ${ }^{14}$

Seen in light of the foregoing analysis, this article subscribes to the analytical definition of civil society, and sees all non-state forces as actors to be located in the broader civil society sphere, but which also at times may be driven by market logics and maintain more or less explicit links with the

10 Heinrich Assessing and Strengthening Civil Society Worldwide: The CIVICUS Civil Society Index (2004); and Dekker "Civicness: From Civil Society to Civic Services?" 200920 Voluntas 220.

11 For an in-depth analysis in the philosophical origins and conceptual problems associated with "civil society", see Hyden and Hailemariam 2003 38(2) Africa Spectrum 216-217.

12 Konozewski "Building the Institutions of Civil Society" in Micou and Lindsnaes (eds) The Role of Voluntary Organisations in Emerging Democracies (1993) 136; and Schuller "Haiti's 200Year Ménage-à-Trois: Globalisation, the State, and Civil Society" 2007 35(1) Caribbean Studies 141156

13 Murray The African Commission on Human and Peoples' Rights and International Law (2000) 33; and Mutua Human Rights: A Political and Cultural Critique (2002) 22.

14 Quoted in Karim and Leve "Privatizing the State: Ethnography of Development, Transnational Capital, and NGOs' Political and Legal' 200124 Anthropology Review 5354. 
state. It is also important to note that the civil society sphere is not only occupied by groups working for "civic" values. ${ }^{15}$ Extrapolating from the above and based on the observable indices of human-rights normativization processes and praxis on the African continent, it is contended that "civil society" should encompass independent groups of activists, private individuals, scholars, African writers, professional groups, research institutes, media, artisans, religious organizations, local leaders, traditional societies, unaffiliated persons, and networks existing within the African region, or outside Africa but with focus on African issues, without subservience or duty of allegiance to any ruling administration or government in Africa. ${ }^{16}$ This rendition appears more suitable for the developmental situation of Africa.

\section{THE AFRICAN CHARTER AND THE PROMISE AND DILEMMAS OF A REGIONAL HUMAN-RIGHTS SYSTEM}

Flowing from the dominant thought that regional arrangements are more effective in providing consensual normative human-rights standards that will respond directly to regional peculiarities, ${ }^{17}$ Africa's response manifested in the evolution of a human-rights system largely tailored along the trajectories of African socio-cultural and developmental needs.

Similar to the European and Inter-American regional human-rights systems, Africa has a distinct regional human-rights system encompassing diverse institutions and normative frameworks. At the core of the African regional human-rights system is the African Charter adopted by the defunct Organization of African Unity (OAU) on 26 June 1981. Although the OAU was not primarily concerned with human rights (as their omission in the establishing instrument - the Charter of the Organisation of African Unity - indicates), the organization soon became challenged by the legacy of dictatorships in many parts of Africa. Today, the successor of the OAU is the African Union (AU), established in July 2001 at the 37th Summit of all African Heads of State and Government. ${ }^{18}$

15 Alexander The Civil Sphere (2006); Almond and Verba The Civic Culture (1989); and Anheier "Reflections on the Concept and Measurement of Global Civil Society" 2007 18(1) Voluntas 110

16 Olowu An Integrative Rights-Based Approach to Human Development in Africa (2009) 279.

17 Shelton "The Promise of Regional Human Rights Systems" in Weston and Marks (eds) The Future Of International Human Rights (1999) 351. See also Rosas "Economic, Social and Cultural Rights in the External Relations of the European Union" in Eide, Krause and Rosas Economic, Social and Cultural Rights: A Textbook 2ed (2001) 479 484-487.

18 The AU succeeded the OAU pursuant to a Constitutive Act ratified by all African Heads of State and Government in 2001. For further discussion, see Olowu "Regional Integration, Development and the African Union Agenda: Challenges, Gaps and Opportunities" 2003 13(1) Transnational Law \& Contemporary Problems 211 213-215; Nmehielle "The African Union and African Renaissance: A New Era for Human Rights Protection in Africa?" 20037 Singapore Journal of International \& Comparative Law 412; and Beyani "Recent Developments in the African Human Rights System 2004-2006" 20077 Human Rights LR 582. 
As of today, all African states are parties to the African Charter. In terms of normative frameworks, some of the foremost treaties that articulate the African regional human-rights system are the African Charter Governing Specific Aspects of the Refugee Problem in Africa, 1969, which entered into force in 1974; the African Charter on Human and Peoples' Rights, 1981, which entered into force in 1986; the African Charter on the Rights and Welfare of the Child, 1990, which entered into force in 1999; the Protocol to the African Charter on Human and Peoples' Rights Establishing the African Court on Human and Peoples' Rights, 1998, which entered into force in 2004; and the Protocol to the African Charter on Human and Peoples' Rights on the Rights of Women, 2003, which entered into force in 2005. Elaborating on these treaties and filling the gaps on various other issues affecting the African continent are numerous other non-binding documents, such as resolutions, declarations and guidelines. These have been covered in considerable detail elsewhere and should not becloud our discussion here. ${ }^{19}$

A common thread in the vast literature on the African Charter is the depiction of its uniqueness in normative terms. In very clear terms, the African Charter shuns the tri-generational approach to human rights contrary to that embraced by the United Nations (UN) human-rights system as well as the European and Inter-American regional human-rights frameworks. On equal footing and with equal force, the African Charter equates all humanrights as essential, interrelated and universal for Africans. ${ }^{20}$ It is remarkable to note that this rendition of universality, interdependence and interrelatedness of all human rights pre-dated the principle later captured by the Vienna Declaration on Human Rights and Plan of Action that resulted from the Second World Human Rights Conference in June 1993. The African Charter also enunciated "peoples' rights", that is, rights which are to be appropriated by human beings in collective terms. These are the inalienable right to self-determination and socio-economic development (Articles 19$20)$; right to exercise autonomy over their wealth and natural resources (Article 21); right to economic, social and cultural development as well as right to development (Article 22); right to national and international peace and security (Article 23); and right to satisfactory environment (Article 24).

The African Charter also occupies the pride of place as the only humanrights treaty that debuted with a set of "duties" of individuals, correlative to the enjoyment of enumerated rights. These duties include those towards family and society as well as other recognized communities and the duty to exercise one's rights within the context of collective social and moral interests (Article 27); the duty towards fellow human beings in promoting and maintaining non-discrimination and social harmony (Article 28); and the duty of an individual to promote and safeguard family life, parental care, national service, payment of taxes, and the defence of social solidarity (Article 29).

Finally, departing from all other human-rights treaties before it, the African Charter makes no provision for derogation clauses.

19 Olowu "The Regional System of Human Rights Protection in Africa" in Sloth-Nielsen (ed) Children's Rights in Africa: A Legal Perspective (2008) 13, 14 and 26; and Heyns and Killander Compendium of Key Human Rights Documents of the African Union (2010).

207 th preambular paragraph, African Charter. 
The philosophical basis for the distinctive features of the African Charter lies in the early recognition by African leaders, acting on the impetus of the intelligentsia of the period, that the African society operates in communal ways. $^{21}$

In terms of implementation, the African Charter established the African Commission on Human and Peoples' Rights (African Commission) to monitor and promote the implementation of the African Charter as well as all other human-rights instruments that may be subject to its jurisdiction. The African Commission was inaugurated in 1987. The Commission carries out its mandate through states' periodic reports; individual complaints procedure; inter-state complaints procedure; and promotional activities. After deliberating on a complaint ("communication"), the Commission issues its recommendations to the states concerned through the Assembly of Heads of State and Government (Articles 52-54, African Charter, 1981).

Apart from the African Commission, other treaty monitoring and implementation mechanisms within the African regional human-rights system include the African Committee on the Rights and Welfare of the Child; the African Court on Human and Peoples' Rights (African Court). To this list should be added a plethora of Special Rapporteurs and Working Groups on various themes pertaining to Africa established by the African Commission in consonance with its promotional mandate. ${ }^{23}$

It must be admitted that even with all its bright promise as a regional humanrights treaty, the African Charter nevertheless birthed a human-rights system with numerous inherent shortfalls. One critical area reflecting this was the "claw-back clauses" (that is, those provisions which allow a state to limit the guaranteed rights to the extent permitted by municipal law). These provisions have become an escape route for some African states against whom complaints of treaty violations have been levied. ${ }^{24}$ Compounding

21 Mutua "The Banjul Charter and the African Cultural Fingerprint: An Evaluation of the Language of Duties" 1998 38(2) Virginia Journal of International Law 339 359-364; and Hollenbach 1998 26(2) The Journal of Religious Ethics 308. For an extensive description of the drafting history of the African Charter up to its adoption in 1981, see Ramcharan "The Travaux Preparatoires of the African Commission on Human and Peoples' Rights' 199213 Human Rights Quarterly 307-314. The following documents are also very vital to a proper understanding of the philosophical and historical basis of the African Charter: "[Mbaye] Draft African Charter on Human and Peoples' Rights" OAU Doc CAB/LEG/67/1 (1979), reprinted in Heyns Human Rights Law in Africa (1999) 65-77; "[Dakar] Draft African Charter on Human and Peoples' Rights' OAU Doc CAB/LEG/67/3/Rev1 (1979), reprinted in Heyns Human Rights Law in Africa 81-91; and Report on the Draft African Charter presented by the Secretary-General at the 37th Ordinary Session of the OAU Council of Ministers, held in Nairobi, Kenya, 15-21 June 1981 OAU Doc CM/1149 (XXXVII) (1981), reprinted in Heyns Human Rights Law in Africa 92-105.

22 Articles 52-54, African Charter.

${ }^{23}$ Olowu in Sloth-Nielsen (ed) Children's Rights in Africa: A Legal Perspective (2008) 13, 14 and 26 .

24 See, eg, Communications 147/95 and 149/95 Sir Dawda K. Jawara vs The Gambia, 13th Annual Activity Report, and Communications 140/94, 141/94 and 145/95 Constitutional Rights Project, Civil Liberties Organisation and Media Rights Agenda vs Nigeria, 13th Annual Activity Report, where the governments of the Gambia and Nigeria, respectively, based their defences on the "claw-back clauses" in the provisions of the African Charter allegedly violated. See further discussions in Murray "Decisions by the African Commission on Human 
these normative shortfalls was the structurally weak enforcement framework for the African Commission. ${ }^{25}$ While the African Commission is obliged under Articles 52-54 of the African Charter to transmit its annual report and recommendations on communications to the Assembly of Heads of State and Government (the Assembly), no mechanism exists for following up such recommendations and none exists on what the Assembly should do with such recommendations. Eno summed up the scenario this way:

'Unlike other regional and global human rights' bodies, the Commission has not developed any follow-up mechanism to ensure implementation of its recommendations ... This has been very frustrating especially for the victims who have to pursue the execution of the decisions on their own. Because there is no pressure from the Commission, states have tended to turn a blind eye to the recommendations and a deaf ear to the victims' pleas for compliance."26

The African regional human-rights system also suffers from endemic resource constraints with many of its organs and activities largely reliant on support from foreign donors.

With the frustrations of inefficacy and under-funding seriously affecting the African Commission, the reluctance of the Assembly to provide commendable backing for the work of the Commission, and the nonchalant attitude of African states to implement the recommendations of the African Commission expeditiously, it took no time for African scholars and activists and their nonAfrican counterparts interested for various reasons in African matters, to commence an enduring scathing criticism of the African Charter, the African Commission and indeed the entire African regional human-rights system as "paper tiger", 28 "toothless bullog", ${ }^{29}$ "sad joke ... farce ... and the hollowest of

and Peoples' Rights on Individual Communications under the African Charter on Human and Peoples' Rights" 199746 International \& Comparative Law Quarterly 412; and Odinkalu "The Role of Case and Complaints Procedures in the Reform of the African Regional Human Rights System" 2001 1(2) African Human Rights LJ 225241.

25 See fuller analysis of these issues in Kufuor "Safeguarding Human Rights: A Critique of the African Commission on Human and Peoples' Rights" 199318 Africa Development 65 66-69; Mutua "The African Human Rights Court: A Two-Legged Stool?" 1999 21(2) Human Rights Quarterly 342 344; and Flinterman and Henderson "The African Charter on Human and Peoples' Rights" in Hanski and Suksi (eds) An Introduction to the International Protection of Human Rights: A Textbook (1999) 387 390-391.

26 Eno "The Place of the African Commission in the New African Dispensation" 200211 African Security Review 6367.

27 Murray "The African Charter on Human and Peoples' Rights 1987-2000: An Overview of Its Progress and Problems" 2001 1(1) African Human Rights LJ 1 12-13; Packer and Rukare "The New African Union and Its Constitutive Act" 200296 American Journal of International Law 365; and Viljoen "A Human Rights Court for Africa, and Africans" 200430 Brooklyn Journal of International Law 1 63-64. See particularly Activity Report of the African Commission on Human and Peoples' Rights, Submitted in Conformity with Article 54 of the African Charter on Human and Peoples' Rights, Thirteenth Ordinary Session 24-28 June 2008, EX.CL/446(XIII), par 110-121, where the African Commission lamented that it "continues to experience acute capacity constraints. This is exacerbated by the expanded scope of work of the Commission since its establishment. The staffing situation will worsen with the departure of 6 short-term staff, 3 Legal Experts, and 2 interns at the end of December 2007".

28 Bonzie-Simpson "A Critique of the African Charter on Human and Peoples' Rights" 198831 Howard LJ 643; Umozurike "The Protection of Human Rights under the Banjul (African) Charter on Human and Peoples' Rights" 1988 African Journal of International Law 1 83; and 
pretences", 30 "facade, a yoke that African leaders have put around our necks ..., ${ }^{31}$ and "juridical misfit", ${ }^{32}$ among numerous other desultory labels. It has indeed become a pastime for scholars lacking fresh ideas to pounce on the perceived weaknesses or failures of the African regional human-rights system since it provides fertile source for grandstanding and self-serving pontifications.

It is remarkable to mention that notwithstanding that the OAU Assembly, consisting of strange ideological bedfellows as they were, had adopted the African Charter in 1981, and ensuring its relatively early entry into force in 1986, the clamour for the radical modification of the African human-rights system had commenced as soon as the African Charter emerged. ${ }^{33}$ In other words, the initial euphoria that welcomed the novel African human-rights treaty had evaporated into a gale of criticisms from the intellectual constituency of the civil society.

It is regrettable that critical writers often fail to remember the circumstances under which the African Charter and its resultant regional human-rights system were birthed. Rational scholars and jurists have shown time and again that what evolved in 1981 as the African Charter was in fact the best form of compromise possible in the Africa of that era. In an age when ruthless dictators, one-party oligarchies, and military despots in the style of Jean-Bedel Bokassa (Central Africa), Idi Amin (Uganda), Fernando Marcias Nguema (Equatorial Guinea), Mobutu Sese Seko (Zaire), Mengistu Haile Miriam (Ethiopia), Siad Barre (Somalia) and Kamuzu Banda (Malawi), and many sittight leaders held sway over the destiny of Africans, it should even be to the eternal credit of the peoples of Africa that any regional human-rights treaty emerged in 1981 at all. As Keba Mbaye, arguably the propelling spirit behind the African Charter, asserted:

"We have already highlighted the inadequacies of the norms conceived and elaborated in the Charter. The criticisms that have been made about the prospect are perhaps too harsh. We must remember that in 1981, the year in which the African Charter was adopted, Africa was not prepared to accept, either materially or institutionally, anything that was not contained in the African Charter on Human and Peoples' Rights."

Anthony "Beyond the Paper Tiger: the Challenge of a Human Rights Court in Africa" 199732 Texas International LJ 511518.

29 Udombana Human Rights and Contemporary Issues in Africa (2003) 125.

30 Robertson Crimes against Humanity: The Struggle for Global Justice (2000) 62, 63 and 64.

31 Mutua "The African Regional Human Rights System in Comparative Perspective" 1993 Review of the African Commission on Human and Peoples' Rights 511.

32 Odinkalu "Analysis of Paralysis or Paralysis of Analysis? Implementing Economic, Social and Cultural Rights under the African Charter on Human and Peoples' Rights" 200123 Human Rights Quarterly 327328.

33 Nmehielle "Development of the African Human Rights System in the Last Decade" 200411 Human Rights Brief 6 6-7; and Mbondenyi Investigating the Challenges in Enforcing International Human Rights Law in Africa: Towards an Effective Regional System (Unpublished LLD Dissertation, University of South Africa, 2008) 21.

34 Quoted in Nmehielle "Towards an African Court of Human Rights: Structuring and the Court" 2000 6(1) Annual Survey of International \& Comparative Law 14 . See also Heyns "The African Regional Human Rights System: In Need of Reform" 2001 1(2) African Human Rights LJ 155 157; and Welch Jr "The African Commission on Human and Peoples' Rights: A Five-Year Report and Assessment" 1992 14(1) Human Rights Quarterly 43. 
Despite the threats of formidable normative, structural, fiscal and political impediments that had almost rendered the African Charter, the African Commission and the entire African regional human-rights system stillborn or at best comatose, the African regional human-rights system, its norms and institutions have achieved commendable mileage and should be so commended.

Although the African Charter has been the subject of robust criticism, it remains a milestone in the history of human-rights treaty-making in Africa, because before its adoption, human rights were perceived as matters within the domestic jurisdiction of the member states of the defunct OAU. ${ }^{35}$ Since its emergence, however, a human-rights system has evolved and looms large. Today, hardly would any African government be bold enough to assert that human rights are matters within its domestic jurisdiction. If nothing else, the culture of impunity is no longer the standard of regime behaviour in Africa.

\section{CIVIL SOCIETY AND OUTCOMES OF THE AFRICAN REGIONAL HUMAN-RIGHTS SYSTEM}

The role of civil society in Third World human-rights work has received increasing attention in recent years, to such an extent that the 1990s could largely be regarded as "the decade of civil society". This reflects a popular opinion that civil society groups are in some way better at human rights-work than governmental agencies. ${ }^{36}$ This positive view of civil society is a result of dissatisfaction with bureaucratic instruments, and a paradigm shift in humanrights discourse that stresses the active participation of local actors in human-rights processes; an approach traditionally characteristic of civil society groups. However, much as this view might be true and appealing, the adoption of the rhetoric does not necessarily entail an automatic practice. The problem lies in putting the participation rhetoric into practice within different socio-cultural milieus. As already discussed, the term "civil society" is also an umbrella concept that covers a wide range of organizations and actors with different backgrounds that could reflect diverse target beneficiaries, donors, areas of operational focus, principles, mission and overall development goals. In this segment, I explore the participation of the civil society in the activities of the African regional human-rights system especially relating to the African Commission.

From standard-setting to data-gathering and implementation monitoring, civil society has been a key actor throughout all the epochs of human-rights development. ${ }^{37}$ This reality presents itself across the international, regional and national contexts, albeit with varying methods, successes and

35 Mahmud "The State and Human Rights in Africa in the 1990s: Perspectives and Prospects" 1993 15(3) Human Rights Quarterly 485; and Naldi The Organisation of African Unity: An Analysis of its Role 2ed (1999) 6.

${ }^{36}$ Tusalem "A Boon or a Bane? The Role of Civil Society in Third- and Fourth-Wave Democracies" 2007 28(3) International Political Science Review 361 364-366.

37 Brett "Non-Governmental Actors in the Field of Human Rights" in Hanski and Suksi (eds) An Introduction to the International Protection of Human Rights: A Textbook (1999) 399. 
challenges. ${ }^{38}$ Emanating from the robust engagement of civil society in Europe, for instance, states that wish to join the European Union must first accede to the European Convention on Human Rights, and those wishing to take advantage of the European Union's Generalised System of Preferences must first ratify several human-rights treaties. ${ }^{39}$

For the African regional human-rights system, the pathways to the present state of its development have revolved almost entirely on the activism of the civil society. Through the series of communications, petitions, debates, and draft resolutions presented to the African Commission over the past 24 years of its establishment, significant milestones have been realized in the areas of access to the Commission; interpretation of the African Charter; implementation reporting and monitoring as well as remediation of alleged violations of the African Charter.

Regarding access to the African Commission, whereas the African Charter had omitted any mention of individual communications, ${ }^{40}$ the African Commission has through its Rules of Procedure, and practice, over the years evolved a process that allowed individuals and civil society groups to submit communications on alleged violations, through the expansive interpretation of articles 55 and 56 of the African Charter. ${ }^{41}$ Such has been the rapid evolution of this process that non-victims could now submit communications to the African Commission, including those brought under the actio popularis doctrine. ${ }^{42}$ Cases demonstrating this innovation include Free Legal Assistance Group, Lawyers' Committee for Human Rights, Union InterAfricaine des de l'Homme, and Les Témoins de Jehovah $v$ Zaire, ${ }^{43}$ Malawi Africa Association, Amnesty International v Mauritania, ${ }^{44}$ Centre for Minority Rights Development (Kenya) and Minority Rights Group International on behalf of Endorois Welfare Council $v$ Kenya, ${ }^{45}$ and Centre on Housing Rights and Evictions (COHRE) v Sudan, ${ }^{46}$ among others. These decisions have received several analytical considerations. ${ }^{47}$ This trend could

${ }^{38}$ Brett in Hanski and Suksi (eds) An Introduction to the International Protection of Human Rights: A Textbook (1999) 403-410.

39 Hathaway "Why Do Countries Commit to Human Rights Treaties?" 2007 51(4) Journal of Conflict Resolution 588. See also Jenkins "We Have a Lot of Goodwill, but We Still Need to Eat ...': Valuing Women's Long Term Voluntarism in Community Development in Lima" 2009 20 Voluntas 1517 , for a discussion on the Inter-American context.

40 Articles 55 and 56.

41 Pedersen "Standing and the African Commission on Human and Peoples' Rights" 2006 6(2) African Human Rights LJ 407410.

42 Ibid.

43 9th Annual Activity Report: 1995-1996, Communications 25/89; 47/90; 56/91 and 100/93.

44 13th Annual Activity Report: 1999-2000, Communications 54/91; 61/91; 98/93; 164/97; and $210 / 98$.

45 Communication 276 / 2003, 4 February 2010.

46 Communication 296/2005, 29 July 2010.

47 Pedersen 2006 6(2) African Human Rights LJ 410-411; Naldi "Limitation of Rights under the African Charter on Human and Peoples' Rights: The Contribution of the African Commission on Human and Peoples' Rights" 2001 17(1) South African Journal of Human Rights 109 112-116; Ocheje "In the Public Interest': Forced Evictions, Land Rights and Human Development in Africa" 2007 51(1) Journal of African Law 176 206; Viljoen and Louw "State Compliance with the Recommendations of the African Commission on Human and Peoples' Rights, 1994-2004" 2007 The American Journal of International Law $12-11$; Centre on Housing Rights and Evictions (COHRE) vs Sudan, Communication 296/2005, 
not have been contemplated by any critic in the early years of the African Charter.

Although writers such as Odinkalu had condemned the African Charter's provisions as being "opaque and difficult to interpret", ${ }^{48}$ within the past three decades of the African Charter's adoption, the scantily worded provisions of the treaty have received substantive elaboration, some of which are quite outstanding in promoting the overall developmental goals of pan-Africanism. ${ }^{49}$

One manifestation of the positive role of the African Commission was the case of Social and Economic Rights Action Centre and the Centre for Economic and Social Rights v Nigeria (hereinafter "SERAC's Case"). ${ }^{50}$ In many respects, SERAC's Case represented a watershed in the implementation of economic, social and cultural rights in Africa. Particularly significant was the African Commission's emphatic assertion that "there is no right in the African Charter that cannot be made effective". ${ }^{51}$ The African Commission thus deserves to be commended for breaking the ice on the African dimension to the trichotomization rhetoric that categorizes human rights into three generations. ${ }^{52}$ It was helpful that the African Commission attempted to define the scope and content of some of the rights allegedly violated. If nothing at all, the interpretations given could inspire future communications on similar subjects.

The SERAC decision also marked the first and most comprehensive attempt by the African Commission to interpret the implications of many economic, social and cultural rights provisions in the African Charter in a single communication. In essence, never again should any African or African human-rights group develop cold feet in bringing a communication on any economic, social and cultural rights norm before an African regional human-

http://www.escr-net.org/caselaw/caselaw_show.htm?doc_id=1333625 (accessed 2012-0321); and Centre for Minority Rights Development (Kenya) and Minority Rights Group International on behalf of Endorois Welfare Council vs Kenya, Communication 276/2003, http://www.escr-net.org/caselaw/caselaw_show.htm?doc_id=1216218 (accessed 2012-0321).

48 Odinkalu "The Individual Complaints Procedures of the African Commission on Human and Peoples' Rights: A Preliminary Assessment" 19988 Transnational Law \& Contemporary Problems 359398.

49 Numerous commentators have recorded most of the jurisprudential developments in this regard. See, eg, Evans and Murray The African Charter on Human and Peoples' Rights: The System in Practice 1986-2000; Musila "The Right to an Effective Remedy under the African Charter on Human and Peoples' Rights" 2006 6(2) African Human Rights LJ 442; and Dersso "The Jurisprudence of the African Commission on Human and Peoples' Rights" 2006 6(2) African Human Rights LJ 358.

50 Communication 155/96, Decision of the African Commission on Human and Peoples' Rights, 30th Ordinary Session, Banjul, The Gambia, 13-27 October, 2001, OAU Doc ACHPR/COMM/A044/1, Oct. 2001 (SERAC's Case). The author's choice of this acronym for the case under consideration is a deliberate departure from popular scholarly usage of Ogoni Case. The reasons for author's novel choice was clarified in Olowu "From Defiance to Engagement: An Evaluation of Shell's Approach to Conflict Resolution in the Niger-Delta" 2010 10(3) African Journal on Conflict Resolution 75 93-94.

51 SERAC's Case supra par 68.

52 For a discussion of Karel Vasak's original theory of three generations of human rights and its irrelevance in the African regional context, see Kumado "Africa and Human Rights since Karel Vasak's Three Generations" in Fernando (ed) Human Rights at the Dawn of the Twenty-First Century: Karel Vasak Amicorum Liber (1999) 273277. 
rights body. SERAC's Case is indeed a veritable locus classicus on those rights. In another way, the "reading-in" approach adopted by the African Commission in recognizing the right to shelter and the right to food, and in holding that these rights are implicit in the combined effect of articles 4, 14, 16 and 18 signalled a demonstration of the capacity of the African regional human-rights monitoring system to be an activist machinery when it is willing to do so.

Perhaps in its most remarkable dimension, the effect of the partnership between the Social and Economic Rights Action Centre and the Centre for Economic and Social Rights in SERAC's Case accentuates the positive impact that collaborative strategies might bring about in giving life and meaning to economic, social and cultural rights norms within regional systems. This should be a pointer towards strengthening networking among African human-rights groups and activists in deepening judicial and quasijudicial approaches to economic, social and cultural rights implementation in Africa, more so, with the establishment of the African Court.

Jettisoning the age when "many Commissioners were more concerned with a literal interpretation of the enabling document than with the flexibility required by Articles 60 and 61 of the Charter", ${ }^{53}$ the African Commission has stepped up its profile of expansive interpretation of the core African humanrights treaty.

Beyond normative elaboration, the African regional human-rights system has increasingly widened the scope of opportunities for the involvement of the civil society in the system. Departing from the earlier years when the African Commission was reluctant to embrace civil society agitation for proactive promotional efforts by the Commission, encouraging friendly relations to have evolved between the African Commission and the civil society as partners in achieving the goals of the African Charter. ${ }^{54}$ It is noteworthy that the rapport between the African Commission and civil society groups has led to the internal transformation of the operations and agenda of the entire regional human-rights system over the past decades. After all, it was through civil society advocacy that special rapporteurs were appointed and numerous critical African issues on which the African Commission was traditionally uncommunicative have received attention through statements, declarations, and action, so much that this development has earned the African Commission's another criticism of "too much reliance on NGOs"! !

Through streamlined criteria, observer status is granted to established civil society groups to participate in the activities of the organs of the African regional human-rights system. Such has been the involvement of the civil society in the work of the African Commission, for instance, that twelve out of the nineteen resolutions proposed by the civil society forum at the 46th

\footnotetext{
53 Umozurike "The African Charter on Human and Peoples' Rights: Suggestions for More Effectiveness" 2007 13(1) Annual Survey of International \& Comparative Law 179182.

54 Harrington "Special Rapporteurs of the African Commission on Human and Peoples' Rights" 2001 1(2) African Human Rights LJ 247 250-251.

55 Murray 2001 1(1) African Human Rights LJ 12.
} 
session of the Commission held in Banjul, the Gambia, in November 2009, were adopted by the African Commission. ${ }^{56}$ It was significant that these resolutions were on such themes as measures to end impunity for humanrights violations; the impact of climate change on human rights; the right to freedom of association; and the impact of the global financial crises on vulnerable groups like the poor, women, children, refugees and displaced persons, indigenous peoples, the disabled and persons living with HIV/AIDS, among others. ${ }^{57}$

Apart from the African Commission, even the Assembly has signalled its radical departure from reaction to cooperation with the civil society. In the Grand Bay (Mauritius) Declaration and Plan of Action, $1999,{ }^{58}$ adopted in the twilight days of the OAU, the Assembly not only recognized that the civil society has played a significant role in the promotion and protection of human rights in Africa, ${ }^{59}$ but also declared that the "development and energization of the civil society" is vital in the process of creating conducive human societies in Africa. ${ }^{60}$ The Declaration also recognizes the importance of promoting African civil society and urged African governments to offer "constructive assistance to civil society" so as to consolidate democracy and development. ${ }^{61}$

Regrettably, however, rather than build a concerted stream of collaboration with the African Commission that would enhance its work, experience shows that the increasing responsiveness of the African Commission to openness is often abused. On a number of occasions, the liberal approach of the Commission to the issue of standing (access) has been subjected to abuse. From instances where communications were filed without adequate information having been obtained by the group acting for the victims ${ }^{62}$ to instances where communications are withdrawn mid-way without substantial explanation, ${ }^{63}$ or without active prosecution. ${ }^{64}$ There is

56 International Service for Human Rights (ISHR), Analytical Overview of 46th Session of the African Commission on Human and Peoples' Rights, 11-25 November 2009, Banjul, the Gambia, 2.

57 International Service for Human Rights (ISHR), Analytical Overview of 46th Session of the African Commission on Human and Peoples' Rights, 11-25 November 2009, Banjul, the Gambia, 3.

58 Organisation of African Unity (OAU), First Ministerial Conference on Human Rights in Africa, Mauritius, 12-16 April 1999, reprinted in 199911 African Journal of International \& Comparative Law 352-357.

59 Organisation of African Unity (OAU), First Ministerial Conference on Human Rights in Africa, Mauritius, 12-16 April 1999, reprinted in 199911 African Journal of International \& Comparative Law, preambular par 13.

60 Organisation of African Unity (OAU), First Ministerial Conference on Human Rights in Africa, Mauritius, 12-16 April 1999, reprinted in 199911 African Journal of International \& Comparative Law, Article 10.

61 Organisation of African Unity (OAU), First Ministerial Conference on Human Rights in Africa, Mauritius, 12-16 April 1999, reprinted in 199911 African Journal of International \& Comparative Law, Article 17.

62 Communication 269/2003, Interights (on behalf of Safia Yakobu Husaini) v Nigeria, 18th Annual Activity Report, Annex III.

63 Communication 273/2003, Centre for Advancement of Democracy, Social Justice, Conflict Resolution and Human Welfare v Nigeria, 18th Activity Report, Annex III; B v Kenya, 17th Annual Activity Report, Annex III.

64 Communication 264/2002, Association Que Choisir Benin v Benin, 18th Annual Activity Report, Annex III. 
also the incidence of misleading communications such as I described elsewhere as "subterfuge activism" by some civil society groups. ${ }^{65}$

The spate of spurious and ill-conceived complaints only bogs down the African Commission and diminishes its capacity in no little way.

The whole essence of the account above is to show that more than ever seen in the 1980s, a broad spectrum of platforms exists which unequivocally points in the direction that the civil society should march in the struggle for effective human-rights culture in Africa. The immediate challenge then becomes how to reposition the civil society towards this end.

\section{FUTURE OF THE AFRICAN REGIONAL HUMAN- RIGHTS SYSTEM: REPOSITIONING THE CIVIL SOCIETY}

Beyond doubt, the emergence and contribution of civil society groups remain indelible in the evolution, promotion and protection of human rights throughout Africa. On a continent where states habitually convert the platform for them to articulate the human rights profiles and challenges frankly within their jurisdictions into one of self-flattery, dedicated to painting brilliant pictures of human-rights progress within their respective domains. In the prevalent tradition of African states, no effort is made to present humanrights abuses truly. In many cases, even national human-rights institutions are compromised by their governments, thereby defeating the whole essence of states' periodic reporting mechanism. Were the treaty monitoring bodies of the African regional human-rights system to rely exclusively on the reports from states and their representatives, the goals of having the system at all would have crumbled. This is what brings the civil society to the fore in calibrating the future and prospects of the African regional human-rights system.

Following his holistic survey of the visibility and performance of the African regional human-rights system, Viljoen had described the scenario this way:

\footnotetext{
"Despite the vastness of the African continent and the frequency of human rights reports and allegations, very few communications have reached the African Commission. At the domestic level, many factors account for this small caseload, among them illiteracy, political instability or war, absence of civil society, lack of legal aid, lack of access to justice, onerous local remedies, dysfunctional court systems, and corruption."
}

In contemporary African regional human-rights experience, the civil society has become an integral part of the African regional human-rights system, through the observer status usually granted to its various components' focusing on women's rights, children's rights, refugees' rights, prisoners' rights, gays' and lesbians' rights, human-rights defenders' rights, indigenous peoples' rights, minority rights, disabled persons' rights, and so on. Through the special forum facilitated by the African Commission, for

65 Olowu An Integrative Rights-Based Approach to Human Development in Africa 155

66 Viljoen 200430 Brooklyn Journal of International Law 21 (author's own emphasis added). 
instance, civil society is able to make statements and submit alternative ("shadow") reports, drawing the attention of the African Commission to grave human-rights abuses which states often ignore, fail, or refuse to report.

Civil society certainly contributes to the work of the African Commission by reason of the insights, depth, balance and vigour it brings to the appreciation and resolution of human-rights challenges in Africa. The active participation of civil society has indeed become vital to the implementation of the promise of the African Charter and all other treaties and norms emanating from it. There is therefore no way the past, present or future of the African regional human-rights systems would be surveyed without a critical review of civil society. After all, a quick investigation reveals that it is from among academics and activists who are particularly vociferous in criticizing the African regional system that membership of its institutions are drawn. As illustration, Professor Umozurike who first christened the African Charter as "a paper tiger" in 1988 not only became a member of the African Commission (1989-1997) but also served as Chairperson (1989-1991). The current lists of the special rapporteurs, focal persons, committees of experts, and working groups throughout the system reveal more about this trend. ${ }^{67}$

Quite apart from attention-seeking and self-promotion among African scholars and activists working in the human-rights arena lie more profound contradictions that have become the albatross around the neck for civil society in Africa. Some commentators have criticized African human-rights civil society actors and organizations as stooges of mainly Western donors to undermine African governments, developmental interests and cultural values. Other criticisms levied against civil society include the absence of accountability; lack of internal democracy; lack of coordination; over-reliance on external donors; obscurity of visions and goals; and tenuous linkages with the state that could foster the efficacy of human-rights work. ${ }^{68}$

So widespread have been the foregoing problems within the African civil society arena that some scholars began questioning whether Africa ever had a "civil society" or whether it will ever be possible for civil society in Africa to pursue altruistic human-rights objectives. ${ }^{69}$ It has been shown that in the effort by the civil society to pursue its political agenda of not capturing the state but expanding its sphere of self-organized life autonomous of the state, African civil society (or whatever appears to be so) had limited its civic

67 International Service for Human Rights (ISHR), Analytical Overview of 46th Session of the African Commission on Human and Peoples' Rights, 11-25 November 2009, Banjul, the Gambia, 21-22.

68 See generally "The Swedish NGO Foundation for Human Rights \& International Human Rights Internship Program 'Nongovernmental Organizations in Sub-Saharan Africa'” 1994 http://www1.umn.edu/humanrts/africa/toc.htm (accessed 2012-03-21); Olowu "Human Development Challenges in Africa: A Rights-Based Approach" 20045 San Diego International LJ 179 215-212; Opoku-Mensah Whither Africa's Civil Society? DIIPER Research Series Working Paper 18 (2009) 11-15; and Mundy, Haggerty, Sivasubramaniam, Cherry and Maclure "Civil Society, Basic Education, and Sector-Wide Aid: Insights from SubSaharan Africa" 2010 20(4-5) Development in Practice 493-494.

69 Makumbe "Is there a Civil Society in Africa?" 1998 74(2) International Affairs 305; Nkwachukwu "Conventional Notion of Civil Society, International Civil Society Organisations and the Development of Civil Society in Africa" paper presented at the International Civil Society Forum, Ulaanbaatar, Mongolia, 8-9 September 2003. 
participation and rendered itself vulnerable to the same antics that have trapped the state. Rather than become active partners in nation-building and developmental programming, civil society actors had become unconscious seekers of favours and personal gains in the whirlwind of neo-colonial statecentric approach to development. ${ }^{70}$ Against the backdrop of the legacy of patronage, clientelism, and patrimonial relationships, a form of politics had ascended on the African political landscape in which civil society actors and organizations found democratic transitions to be veritable opportunities for appropriating wealth, positions and prestige - a scenario perfectly described by Dunn as "politics of the belly", and overshadowed by several other commentators.

Admittedly, the peculiarities of African states - geo-ethnic factions, religious polarizations and over-centralized economies - make the task of human-rights groups arduous. This is because when addressing political contestations, there is always a risk that civil-society organizations get tangled in party politics. After all, most political reform processes carry the stamp of contending political cleavages. African civil society actors continually run the risk of being identified with the government when supporting government-led initiatives, or with the opposition when criticizing the government. ${ }^{72}$

Rather than embarking on the deterministic zero-sum theories propounded by critics of African civil society, it is more relevant, in the context of our present study, to emphasize the need for the civil society in Africa to extricate itself from the trappings of the prebendalism, patriarchy, appeasement, corruption and patronage that have for long being associated with the African state. To this end, I contend that if it had been possible for the civil society to have deployed tactics that have proved useful in bringing the African regional human-rights system to its present stages of achievement, it should be possible to sharpen its frontiers the more in the years ahead, and to respond to the massive problems of poverty, disease, and under-development on the continent. The question of how effective civil society will be in the long run depends upon the emergence of new or the rejuvenation of existing civil society outlets that will irreversibly commit themselves to the tasks of grassroots mobilization, local education for empowerment, and genuine internalization of the principles of good governance that they canvass within national jurisdictions.

Rather than the seemingly gleeful tradition of condemning all that the African regional human-rights system represents, the thrust of civil society

70 Hyden "The Challenge of Domesticating rights in Africa" in Cohen, Hyden and Nagan (eds) Human Rights and Governance in Africa (1993) 256265.

71 Dunn West African States: Failure and Promise: A Study in Comparative Politics (1978) 133. See also Nkwachukwu "Conventional Notion of Civil Society, International Civil Society Organisations and the Development of Civil Society in Africa" paper presented at the International Civil Society Forum, Ulaanbaatar, Mongolia, 8-9 September 2003; Hollenbach 1998 26(2) The Journal of Religious Ethics 311; and Bayart The State in Africa: The Politics of the Belly, translated by Harper (1993) xvii.

72 Clapham Africa and the International System: The Politics of State Survival (1996) 20; Bell and O'Rourke "The People's Peace? Peace Agreements, Civil Society, and Participatory Democracy" 2007 28(3) International Political Science 293295. 
should squarely be how to strengthen this relatively nascent regional humanrights system. One task for civil society is to pursue state compliance with the recommendations of the African Commission with equal energy that celebrates the submission of communications.

A comprehensive agenda for civil society in Africa should be anchored on building broad constituencies that can sustain political commitment and the integrity of governance; creating a supportive environment for partner-ships with similar groups to strengthen strategies and reduce duplication and costs in the regional and international human-rights arena. The agenda should also entail the independent involvement of civil society in budgetary processes as well as participation in policy and programme design at the national levels.

In forging the agenda for the future, discourses on human rights in Africa should revolve around how to enhance the production, dissemination and promotion of knowledge, information and experiences among all the strata of "civil society" in Africa. While civil society has done much in promoting human-rights knowledge at urban African sites, the task should be extended to increased human-rights education campaigns among the rural population.

With the positive climate prevailing between the African Commission and human-rights groups, African civil society should clamour for the compulsory inclusion of comprehensive human-rights modules in all African universities, channelling this suggested idea through the Association of African Universities. After all, the products of these universities sooner than later become policy makers, government advisors, legal draftspersons, lawyers, diplomats, skilled professionals and leaders of the informal sector in African countries.

Despite all its identified problems, civil society in Africa remains a veritable sine qua non to the promotion of alternative discourses and provision of strategic impetus, particularly in the regional human-rights realm.

\section{CONCLUSION}

Africa no longer needs human-rights rhetoric but the practice of human rights in real terms. Africa does not need some esoteric revolution of paradigms but practical and pragmatic approaches to the intersecting questions of human rights, human dignity, human security, human development and good governance. As endemic and unrelenting poverty continues to blemish the face of the African continent and compromise the dignity of Africans, a conscious effort has been made in reawakening the urgent need for civil society in Africa - in all ramifications - to reposition itself and to assume leadership, once again, in championing the latest wave of rights-based democratization and liberation on the platform of the African regional human-rights system.

This article emerged from the overarching premise that a complete understanding of the dynamics of the African regional human-rights system requires a tripartite framework, tracking and theorising participation of three general sets of actors: states, foreign influences, and civil society. Furthermore, while African regional human-rights narrative has been 
particularly dramatic since 1981, binary logics within theories of globalization, human rights and civil society need to be replaced with a tripartite framework. This article has provided an insight for scholars and activists interested in a rich understanding of the African regional humanrights system vis-á-vis the civil society, presenting a calculus that allows for a conversation among its proffered theoretical and practical constructs.

Far from being an ex cathedra pronouncement on all the dynamics that must inform pragmatic civil society responses to the task of entrancing the African regional human-rights system, this paper would have served its purpose if it stimulates further intellectual discourses. 